\title{
MODEL PENGGAJIAN GURU BERDASARKAN PERSPEKTIF ISLAM
}

\section{TEACHER PAYROLL MODELS BASED ON ISLAMIC PERSPECTIVES}

\author{
R. Rahmania' ${ }^{1}$, T.Kurnia ${ }^{2}$, S. Hasbi ${ }^{3}$ \\ Program Studi Ekonomi Syariah Fakultas Ekonomi Islam Universitas Djuanda Bogor \\ Email: rahmaniarisa95@gmail.com
}

\begin{abstract}
This study aims to determine the salary of teachers in schools. The research method used is descriptive using a qualitative research approach. The analysis technique used is miles and hubermen. Based on the results of the study, a teacher payroll model was formed based on an Islamic perspective which the leaders of private schools in Bogor could become a reference for providing policies regarding teacher salaries. These stages are: (1) Conducting a thorough analysis of the description and specifications of teacher positions and assignments, (2) school leaders can make agreements with employees regarding salary determination and policies given in official forums, (3) The process of making school salary structures by School leaders and treasurers can consider the financial capacity of the school, (4) The final stage in the teacher remuneration model is that school leaders can consider giving individual salaries to teachers in accordance with the positions and tasks assigned by using good data management and verification is to supervise teachers after the policy is set.
\end{abstract}

Keywords: Justice, salary, educational institutions, teacher, Models

\begin{abstract}
ABSTRAK
Penelitian ini bertujuan untuk mengetahui penetapan penggajian guru di sekolah. Metode penelitian menggunakan deskriptif dengan menggunakan pendekatan penelitian kualitatif. Tehnik analisis yang digunakan adalah miles and hubermen. Berdasarkan hasil penelitian, maka terbentuklah model penggajian guru berdasarkan perspektif Islam yang oleh pimpinan sekolah swasta di Bogor dapat menjadi rujukan untuk memberikan kebijakan mengenai besaran gaji guru. Tahapan tersebut adalah: (1) Melakukan analisis yang matang mengenai deskripsi dan spesifikasi jabatan guru dan tugas, (2) Pimpinan sekolah dapat melakukan kesepakatan dengan karyawan mengenai penetapan gaji dan kebijakan yang diberikan dalam forum resmi, (3) Proses pembuatan stuktur gaji sekolah oleh pimpinan sekolah dan bendahara dapat mempertimbangkan kemampuan finansial sekolah, (4) Tahapan terakhir dalam model penggajian guru yaitu pimpinan sekolah dapat mempertimbangkan pemberian gaji individual kepada guru sesuai dengan jabatan dan tugas yang dibebankan dengan menggunakan manajemen dan verifikasi data yang baik adalah dengan melakukan pengawasan kepada guru setelah kebijakan ditetapkan.
\end{abstract}

Kata Kunci: Keadilan, Gaji, lembaga pendidikan. Guru, Model.

Risa Rahmania. 2020. Model Penggajian Guru Berdasarkan Perspektif Islam. Jurnal Syarikah 6 (2): 171- 


\section{PENDAHULUAN}

Status guru di masyarakat dan budaya Indonesia masih menempati tempat yang terhormat, namun secara material profesi guru mengalami penurunan dan kurang berkembang. Hampir di seluruh Indonesia penghargaan material terhadap guru sangat minim, bahkan sebagian besar guru berada di bawah garis kemiskinan (Tilaar, 2002:90). Hal ini dibuktikan dengan kehidupan Guru SMPN 1 Montong Gading-Lombok Timur yang menjalani pekerjaan sebagai guru Geografi sekaligus staf tata usaha serta bekerja tambahan sebagai pemulung juga merangkap pedagang keliling untuk memenuhi hidupnya dan keluarga sehari-hari (jpnn.com, 12 Juni 2017).

Upaya pemerintah Indonesia dalam rangka memenuhi kebutuhan guru adalah melalui pencanangan guru sebagai profesi oleh Mantan Presiden Susilo Bambang Yudhoyono pada tanggal 2 Desember 2004 dengan ditetapkannya UU No. 20 Tahun 2003 tentang Sistem Pendidikan Nasional, lahirnya PP No. 19 Tahun 2005 tentang Standar Nasional Pendidikan serta lahirnya UU No. 14 Tahun 2005 tentang Guru dan Dosen yang disahkan tanggal 6 Desember 2005. UU ini juga menekankan tiga aspek penting dalam peningkatan mutu pendidikan di Indonesia dilihat dari tenaga pendidik dan kependidikan, yakni kualifikasi, sertifikasi, dan kesejahteraan (Kunandar, 2007:36).

Berdasarkan hasil observasi sekolah di Kota Bogor mengenai klasifikasi penggajian guru ada keragaman penggajian guru di sekolah non islam, negeri, umum, umum berbasis keagamaan dan model pesantren, dari hasil wawancara dari beberapa guru di Kota Bogor, Gaji guru non PNS di sekolah negeri dan swasta sampai saat ini masih menjadi keprihatinan sejumlah pihak, belum adanya kesamaan serta acuan yang dapat dijadikan dasar terhadap pemberian gaji kepada guru. Gaji yang diterima guru di sekolah non Islam di Kota Bogor mendapatkan gaji sebesar Rp. 2.000.000-Rp. 3.000.000/bulan, guru PNS di SMPN 12 Kota Bogor memperoleh penghasilan sesuai dengan golongan PNS dengan besaran Rp. 1.500.000-Rp. 5.600.000, sedangkan SMP Pesat sebagai salah satu sekolah swasta di Kota Bogor memberikan gaji yang sama untuk para guru yaitu sebesar Rp. 3.200.000-Rp. 3.400.000, SMP IT Al Mustarih dan MTs Al Falaqiyah memiliki sistem penggajian yang hampir sama, guru diberikan gaji sesuai dengan masa kerja mengajar, sedangkan SMP Asyarofah memberikan gaji kepada gurunya beragam dari mulai Rp. 75.000 - Rp. 200.000 sesuai dengan jumlah hari kedatangan.

Islam sejak awal telah memberikan perhatian utama kepada kepentingan gaji karena gaji memiliki pengaruh yang besar kepada masyarakat. Mengingat gaji merupakan hak bagi karyawan yang harus dipenuhi oleh perusahaan, karenanya perusahaan harus berusaha seoptimal mungkin untuk memberikan gaji yang seimbang bagi para karyawan termasuk guru sesuai dengan hasil kerja yang telah diberikan. Perusahaan harus memiliki sistem penggajian yang baik, sehingga gaji yang diterima karyawan dapat diberikan tepat waktu dengan jumlah yang benar (Marlina, 2013:29).

Prinsip keadilan dan anti diskriminasi dalam Islam tidak mengenal sistem kasta atau kelas di masyarakat, pemenuhan ekonomi bagi pekerja yang menjadi kewajiban dan tidak boleh diabaikan oleh para majikan atau pihak yang mempekerjakan. Islam sangat memperhatikan masalah upah pekerja sebagai hak dan gaji atas pekerjaan yang telah mereka kerjakan. Sebegitu pentingnya masalah upah pekerja, maka Islam memberi pedoman kepada para pihak yang mempekerjakan orang lain bahwa prinsip pemberian upah harus mencakup dua hal, yaitu adil dan layak (Ridwan, 2013:253).

\section{MATERI DAN METODE}

\section{Definisi Guru}

Definisi Guru Menurut Undang-Undang Nomor 14 Tahun 2005 tentang guru dan dosen yaitu adalah pendidik profesional dengan tugas utama mendidik, mengajar, membimbing, mengarahkan, melatih, menilai, dan mengevaluasi peserta didik pada pendidikan anak usia dini jalur pendidikan formal, pendidikan dasar, dan pendidikan menengah (Pasal 1 ayat 1 ). 
Guru dalam pandangan Islam mempunyai kedudukan yang tinggi. Keutamaan guru (pendidik) dan tingginya kedudukan guru dalam Islam merupakan realisasi ajaran Islam itu sendiri, Islam memuliakan pengetahuan, sedangkan pengetahuan itu didapat dari belajar dan mengajar, maka sudah pasti agama Islam memuliakan seorang pendidik (Ramayulis, 110:2005).

\section{Teori Gaji (Upah) Tenaga Kerja}

Upah adalah sejumlah pendapatan uang yang diterima oleh buruh dalam satu waktu tertentu akibat dari tenaga dan usaha yang digunakan dalam proses produksi (Yahya, 1998: 393). Gaji cenderung identik dengan pekerja-pekerja, pegawai-pegawai, dan karyawan-karyawan tetap dimana pembayarannya sebulan atau seminggu sekali. Sedangkan upah cenderung diidentikkan dengan pekerja-pekerja kasar, buruh-buruh kasar, buruh-buruh pertanian, dan segala jenis pekerjaan tidak tetap (Sukirno, S. 1994 : 350).

Dalam teori ekonomi upah diartikan sebagai pembayaran ke atau jasa-jasa fisik maupun mental yang disediakan oleh tenaga kerja kepada para pengusaha. Dengan demikian dalam teori ekonomi tidak dibedakan di antara pembayaran kepada pegawai tetap dengan pembayaran ke atas jasa-jasa pekerja kasar dan tidak tetap. Keduanya dinamakan upah (Sukirno, S. 1994 : 350).

\section{Definisi upah / gaji menurut Islam}

Islam menjelaskan mengenai upah secara rinci dalam pembahasan yang termasuk pada pembahasan ijarah yaitu akad atas suatu manfaat dengan adanya kompensasi. Oleh karena itu, transaksi ijarah adalah akad (transaksi) terhadap jasa tertentu dari seorang pekerja dengan suatu kompensasi. Kompensasi diberikan oleh pengontrak pekerja (musta'jir) karena dia memperoleh pelayanan jasa berupa tenaga atau fisik maupun intelektual. Secara umum, ijarah ada dua; pertama, akad yang berkaitan dengan orang yang dikenal dengan transaksi ketenagakerjaan; kedua, akad yang berkaitan dengan barang yang dikenal dengan istilah kerja (Yusanto dan Yunus, 2009:190).

\section{Dasar hukum upah / gaji menurut Islam}

Dasar hukum upah dapat ditemukan di dalam Al-Qur'an dan Al-Hadits Rasulullah SAW yaitu dalam Q.S Al-Qasas ayat 27, Q.S Az-Zukhruf ayat 32, Q.S At-Talaq ayat 6, HR. Muslim, HR. al-Bukhari, dan HR. Abdul Razzaq. Dari dalil-dalil di atas, dapat disimpulkan bahwa memberi upah kepada pekerja diperbolehkan atas jasa/tenaga yang telah dicurahkan. Upah juga merupakan suatu kewajiban dan merupakan hak bagi pekerja untuk memperolehnya dan menjadi kewajiban bagi pengontrak tenaga kerja untuk membayarnya.

\section{Syarat upah / gaji menurut Islam}

Upah merupakan salah rukun dalam akad (transaksi ijarah). Para ulama telah menetapkan beberapa syarat dalam upah, yaitu pertama, upah harus berupa harta yang tetap; dan kedua, upah tidak boleh sejenis dengan barang manfaat dari ijarah, seperti upah menyewa rumah untuk ditempati dengan menempati rumah tersebut (Syafe'I, 2001:129).

\section{Kadar upah / gaji pekerja}

Menurut (Hatta, 2013:210) upah bagi buruh ada dua macam yaitu, upah musamma (tertentu) dan upah mitsli (memadai). Upah tertentu adalah upah yang disebutkan dan ditentukan waktu akad, termasuk upah yang ditentukan adalah upah para pekerja yang diberitahukan terhadap masing-masing dari mereka. Misalnya upah bagi para pegawai pada derajat tertentu atau upah bagi para pekerja dalam pabrik tertentu itu diketahui pekerja yang ada di dalamnya. Sedangkan upah mitsli adalah upah yang sepadan dengan pekerjaan dan sepadan pula dengan pekerja, atau upah yang sepadan dengan pekerja saja.

\section{Macam-macam upah / gaji}

Pekerja dapat diklasifikasikan kepada dua pembagian, yaitu upah atas buruh individual dan upah atas buruh serikat. Terdapat perbedaan jumlah upah dan faktorfaktor yang mempengaruhinya, hal ini sesuai kualitas pekerja yang membedakan antara para pekerja pemerintahan dan pekerja individual, di antaranya adalah para manajer (Zamakhsyari, 2006:238). 


\section{Gugurnya upah / gaji}

Para ulama berbeda pendapat dalam menentukan upah bagi pekerja, apabila barang yang di tangannya rusak. Menurut ulama Syafi'iyyah dan ulama Hanabilah, jika pekerja di tempat yang dimiliki oleh penyewa, ia tetap memperoleh upah. Sementara ulama Hanafiyyah juga hampir senada dengan pendapat di atas, hanya diuraikan lagi:

a) Benda ada di tangan pekerja. Dalam hal ini, jika ada bekas pekerjaan, maka pekerja berhak mendapatkan upah sesuai bekas pekerjaan tersebut. Akan tetapi, jika tidak ada bekas pekerjaannya, maka pekerja berhak mendapat upah atas pekerjaannya sampai akhir.

b) Benda ada di tangan penyewa. Dalam hal ini, pekerja berhak mendapatkan upah setelah selesai bekerja (Syafe'i:136).

c) Asas nilai keadilan dan kelayakan Islam dalam penentuan besaran upah / gaji

Berdasarkan prinsip keadilan, upah dalam masyarakat Islam akan ditetapkan melalui negosiasi antara pekerja, majikan dan Negara. Dalam pengambilan keputusan tentang upah maka kepentingan pencari nafkah dan majikan akan dipertimbangkan secara adil (Sholihin:365). Untuk mempertahankan suatu standar upah yang sesuai, Islam telah memberikan kebebasan sepenuhnya atas mobilisasi tenaga kerja. Disamping itu, memberi kebebasan sepenuhnya kepada pekerja untuk memilih jenis pekerjaan yang dikehendakinya. Demi kemakmuran dan kemajuan Negara, maka perlu untuk menyusun kembali sistem upah sesuai dengan ajaran Rasulullah untuk menentukan upah minimum (Koentjoro:2011).

\section{Sistem penggajian untuk guru dalam Islam}

Gaji guru adalah salah satu unsur yang sangat penting yang dapat mempengaruhi kinerja guru di suatu lingkup pendidikan, sebab gaji guru adalah alat untuk memenuhi berbagai kebutuhan guru sehingga dengan adanya gaji yang diberikan, para guru akan termotivasi untuk bekerja lebih giat (Mulyono,2004). Sistem penetapan upah dalam Islam diantaranya yaitu upah disebutkan sebelum pekerjaan di mulai dan membayar upah sebelum keringatnya kering (Hakim, 202).

\section{Metode Penelitian}

Menurut Nazir (1988), metode deskriptif merupakan suatu metode dalam meneliti status sekelompok manusia, suatu objek, suatu set kondisi, suatu sistem pemikiran ataupun suatu kelas peristiwa pada masa sekarang. Tujuan dari penelitian deskriptif ini adalah untuk membuat deskripsi, gambaran, atau lukisan secara sistematis, faktual dan akurat mengenai fakta-fakta, sifat-sifat serta hubungan antarfenomena yang diselidiki.

Kemudian sumber data yang digunakan dalam penelitian ini yaitu data primer dan sekunder dengan menggunakan teknik pengumpulan data melalui wawancara dan dokumentasi kepada responden. Berdasarkan masalah penelitian yang akan dilakukan oleh peneliti yaitu mengenai manajemen yang diterapkan oleh sekolah swasta yang ada di kota Bogor dalam hal penetapan gaji untuk guru.

\section{Populasi dan Sampel}

Populasi atau universe adalah jumlah keseluruhan dari satuan-satuan atau individuindividu yang karakteristiknya hendak diteliti. Dan satuan-satuan tersebut dinamakan unit analisis, dan dapat berupa orang-orang, institusi-institusi, benda-benda, dan sebagainya (Djawranto, 1994:420). Sampel adalah bagian dari jumlah dan karakteristik yang dimiliki oleh populasi tersebut (Sugiyono,2015:80). Populasi pada penelitian ini yaitu guru dan Kepala Sekolah swasta di Kota Bogor. Penentuan sampling berdasarkan kepada beberapa teknik. Teknik sampling yang digunakan dalam penelitian ini yaitu purposive sampling, dimana teknik pengembilan sampel berdasarkan kepada pertimbangan dan kriteria tertentu. Metode analisis data dilakukan dengan menggunakan metode Miles and Hubermen

\section{HASIL DAN PEMBAHASAN}

\section{Matriks Daftar Cek}

Matriks daftar cek memberikan penjelasan tentang jawaban dari objek penelitian atau informan dari pertanyaan peneliti. Matriks ini digunakan jika peneliti mengetahui variabel dan indikator spesifik yang berkaitan (Miles \& Huberman, 2014). Setiap informan mendapat beberapa 
pertanyaan yang sama guna mengetahui pendapat dan jawaban dari setiap informan.

\section{Keadilan}

Nilai adil dalam sistem penggajian adalah suatu estimasi dari penilaian moral, yang tidak dapat diukur dan diamati sebagai objek pengujian eksperimental oleh sarana-sarana ilmiah (As-shadr, 85:2009). Islam berlandaskan Al-Qur'an dan As-Sunnah sebagai sumber doktrin ekonominya sangat mengarahkan para cendikiawan Islam untuk terus mengeksplorasi pemahaman terkait tatanan-tatanan nilai keadilan Islam agar dapat berlaku sesuai zaman dengan cara melakukan ijtihad dengan mempertimbangkan manfaat dan tidak manfaatnya (mudharat) secara luas dalam hubungan antar manusia (sosial).

Dalam Islam kata adil ditempatkan dalam beberapa artian yaitu:

1) Keseimbangan

Tabel 1 Perbandingan Keseimbangan

\begin{tabular}{|c|c|c|}
\hline No. & S.MP Pesat & SMP As-Syarofah \\
\hline $\mathrm{L}$ & $\begin{array}{l}\text { Adarya lesepakatan antara sekilah } \\
\text { danguru/karyaran }\end{array}$ & $\begin{array}{l}\text { Adanya kesepakatan antara sekolah dan } \\
\text { guru/karyaran }\end{array}$ \\
\hline 2 & $\begin{array}{l}\text { Wahtu jam pulang bekzra ditenhlan } \\
\text { (walaupun kewailban mengajar telah } \\
\text { selesai. belum dininkan pulang jila } \\
\text { belum waltunya pulang/sesaai } \\
\text { houtrak) }\end{array}$ & $\begin{array}{l}\text { Waktu jam pulang belierja tidak } \\
\text { ditentukan (setelah kewaiban nengajar } \\
\text { selesai, dilizickan pulang) }\end{array}$ \\
\hline 3. & $\begin{array}{l}\text { Gaji pokok guru per jam ditentakan } \\
\text { sesaai tinghatan perdidikan }\end{array}$ & $\begin{array}{l}\text { Gall pokok guru per jan bidak } \\
\text { ditentjkan sesuai tinghatan pendidikan }\end{array}$ \\
\hline 4. & $\begin{array}{l}\text { Ada insentif atas tugas dilar } \\
\text { hewailsanmengaiar }\end{array}$ & $\begin{array}{l}\text { Tidak ada insertif atas tugas diluar } \\
\text { kewrajban mengajar }\end{array}$ \\
\hline 5. & $\begin{array}{l}\text { Ada tambahan gail atas guru yang } \\
\text { mengajar lebih dari yang dibebankan }\end{array}$ & $\begin{array}{l}\text { Tidak ada tambahan gä̈ atas guru yang } \\
\text { mengaiar lebih dari yang dibebankan }\end{array}$ \\
\hline 6. & $\begin{array}{l}\text { Penghargaan yang diberikan atas } \\
\text { prestavi yang diperoleh }\end{array}$ & Tidak ada penghargann \\
\hline 7. & $\begin{array}{l}\text { Gail pokok yang diterima guru sudah } \\
\text { termasuk biaya transportasi dan } \\
\text { honsumsintuk gura }\end{array}$ & $\begin{array}{l}\text { Gail pokok yang diterima guru sudah } \\
\text { termasok biaya transportasi dan } \\
\text { konsumsi antuk guru }\end{array}$ \\
\hline 8. & $\begin{array}{l}\text { Garu tidak diizinkan mengajar di } \\
\text { seholah lain }\end{array}$ & Guru dilzinhan mengajar di sekolah lain \\
\hline 7. & $\begin{array}{l}\text { Guru yang memperoleh sertifikasi dari } \\
\text { pemerintah. tidak mempengaruhi gaip } \\
\text { yang diterima di sekolah }\end{array}$ & Belum ada guru yang sudah sertificasi \\
\hline
\end{tabular}

Berdasarkan Tabel 1 adil dalam pengupahan yaitu haruslah adil terhadap dua pihak, perusahaan/pemimpin membayar para karyawan/pekerja yang setara dengan pekerjaannya. Dalam perjanjian (tentang gaji/upah) perusahan (sekolah) dan karyawan perlu membahas mengenai gaji dengan seadil dan sejujur- jujurmya sehingga tidak tejadi kerugian kepada pekerja maupun perusahaan.

Pada proses keadilan pula SMP Pesat dan SMP As-Syarofah menetapkan kebijakan yang diambil guna mempertimbangkan halhal yang mempengaruhi besaran gaji guru yang diterima. Berikut kebijakan yang ditetapkan oleh masing-masing sekolah:

a. Penerimaan kas yayasan berdasarkan jumlah siswa baru.

b. Pendidikan

Tabel 2 Rincian Biaya Transport dan Konsumsi Guru

\begin{tabular}{|c|c|c|c|}
\hline No & Pendidikan & $\begin{array}{l}\text { Transport dan } \\
\text { Konsumsi di } \\
\text { SMP Pesat }\end{array}$ & $\begin{array}{c}\text { Transport } \\
\text { dan } \\
\text { Konsumsi di } \\
\text { SMP As- } \\
\text { Syarofah } \\
\end{array}$ \\
\hline 1 & Diploma & Rp. 60.000,- & \multirow{4}{*}{$\begin{array}{l}\text { Tidak ada } \\
\text { transport dan } \\
\text { konsumsi }\end{array}$} \\
\hline 2 & Strata 1 & Rp. 70.000,- & \\
\hline 3 & Magister & Rp. 85.000,- & \\
\hline 4 & Doktoral & Rp. 95.000,- & \\
\hline
\end{tabular}

Berdasarkan Tabel 2 Yayasan Pesat memberikan kebijakan dengan membedakan besaran transport dan konsumsi kepada guru dan staf sesuai dengan pendidikan terakhir yang ditempuh, hal ini diambil karena mempertimbangkan pengeluaran biaya yang dikeluarkan guru untuk menempuh pendidikan tersebut. SMP As-Syarofah tidak membedakan transport dan konsumsi guru berdasarkan tingkat pendidikan, karena transport dan konsumsi yang diterima guru sudah termasuk kedalam gaji yang diterima setiap bulannya.

Jabatan guru yang memiliki tambahan tugas selain mengajar maka sekolah akan memberikan tunjangan kepada tambahan, SMP Pesat memberikan tunjangan kepada guru yang menerima tugas selain mengajar. SMP As-Syarofah belum memberikan tunjangan kepada guru yang menerima tugas selain mengajar, berdasarkan hasil wawancara kepada pihak SMP As-Syarofah, hal ini diambil dikarenakan pihak sekolah mempertimbangkan biaya pembangunan sekolah terlebih dahulu. 
Persamaan Antara SMP PESAT dan SMP As-Syarofah.

Persamaan antara SMP PESAT dan SMP As-Syarofah antara lain; tidak ada perbedaan antara jenis kelamin guru tidak menjadi pembeda, guru diberikan hak cuti yang sama, guru mendapatkan pelatihan yang sama dan persyaratan dalam kenaikan jabatan,

\section{Pemberian Gaji Kepada Karyawan}

Guru menerima gaji pada hari yang telah ditentukan, guru mendapatkan hari libur. Sedangkan pada SMP PESAT guru dilarang untuk mengajar ditempat lain sementara itu, di SMP As-Syarofah guru diperbolehkan untuk mengajar ditempat lain.

\section{Model Penggajian Guru di Sekolah}

Berdasarkan penelitian yang sudah dilakukan, maka terbentuklah model penggajian guru yang digunakan oleh SMP Pesat, sebagai berikut:

Tahap pertama yaitu proses perencanaan yang dilakukan hanya dengan rapat atau musyawarah, tahap kedua yaitu pelaksanaan pemberian gaji kepada guru, tahap terakhir yaitu evaluasi, evaluasi dapat dilakukan pada saat bulan-bulan awal kebijakan mulai diterapkan sekolah.

\section{Model Penggajian Guru Berdasarkan Perspektif Islam}

Model penggajian guru berdasarkan perspektif Islam yang dapat diterapkan oleh sekolah di kota Bogor yaitu usulan model yang dapat diterapkan oleh sekolah. Tahapan yang dapat dilakukan oleh pimpinan sekolah sebelum memberikan kebijakan mengenai besaran gaji untuk guru. Tahapan tersebut yaitu melakukan analisis yang matang mengenai deskripsi dan spesifikasi jabatan guru dan tugas yang dibebankan sebelum menetapkan kebijakan besaran gaji yang akan diberikan, setelah proses analisis yang matang mengenai deskripsi dan spesifikasi jabatan, dalam penetapan gaji tersebut pimpinan sekolah juga dapat melakukan kesepakatan dengan karyawan mengenai penetapan gaji dan kebijakan yang diberikan dalam forum resmi seperti misalnya rapat awal tahun atau rapat akhir tahun yang mengundang seluruh guru dan karyawan sekolah, proses pembuatan stuktur gaji sekolah oleh pimpinan sekolah dan bendahara dapat mempertimbangkan kemampuan finansial sekolah. Pembuatan stuktur gaji ini diharpakan dapat membantu pimpinan sekolah untuk menjadikan acuan terhadap gaji guru kedepan jika ada perubahan, tahapan terakhir dalam model penggajian guru yaitu pimpinan sekolah dapat mempertimbangankan pemberian gaji individual kepada guru sesuai dengan jabatan dan tugas yang dibebankan dengan menggunakan manajemen dan verifikasi data yang baik adalah dengan melakukan pengawasan kepada guru setelah kebijakan ditetapkan, hasil akhir dari tahapantahapan itu adalah dapat melakukan implementasi, komunikasi dan pengawasan dalam penerapan penggajian guru berbentuk model yang dapat dijadikan acuan sekolah dalam menentukan kebijakan.

\section{KESIMPULAN DAN IMPLIKASI}

Berdasarkan hasil penelitian yang telah dilakukan mengenai model penggajian guru di sekolah Kota Bogor perbandingan penetapan penggajian guru di sekolah kota Bogor dengan menggunakan variabel keadilan dan kelayakan dalam model penggajian guru. Maka dapat ditarik kesimpulan sebagai berikut:

1. Perbandingan penggajian guru yang diberikan SMP Pesat dan SMP AsSyarofah terdapat banyak perbedaan. Perbedaannya yaitu SMP Pesat mempertimbangkan beberapa kebijakan terkait penetapan besaran gaji untuk guru sehingga guru yang berbeda pendidikan terakhir dan jabatannya di sekolah maka akan menerima gaji dan tunjangan yang berbeda namun jika gaji pokoknya disamakan oleh sekolah karena guru diwajibkan untuk berada di sekolah pada waktu yang sama yang telah ditentukan serta guru tidak diizinkan mengajar di lebih dari satu sekolah, 
sedangkan SMP As-Syarofah memberikan gaji yang sama kepada guru walaupun berbeda pendidikan terakhir dan tugas tambahan yang diberikan namun SMP As-Syarofah memberikan kebijakan kepada guru untuk dapat pulang setelah selesai mengajar dan dapat mengaplikasikan ilmunya di lebih dari satu sekolah.

Berdasarkan hasil penelitian, maka terbentuklah model penggajian guru berdasarkan perspektif Islam yang oleh pimpinan sekolah swasta di Bogor dapat menjadi rujukan untuk memberikan kebijakan mengenai besaran gaji guru. Tahapan tersebut adalah: (1) Melakukan analisis yang matang mengenai deskripsi dan spesifikasi jabatan guru dan tugas yang dibebankan sebelum menetapkan kebijakan besaran gaji yang akan diberikan, (2) Setelah proses analisis yang matang mengenai deskripsi dan spesifikasi jabatan, dalam penetapan gaji tersebut pimpinan sekolah juga dapat melakukan kesepakatan dengan karyawan mengenai penetapan gaji dan kebijakan yang diberikan dalam forum resmi seperti misalnya rapat awal tahun atau rapat akhir tahun yang mengundang seluruh guru dan karyawan sekolah, (3) Proses pembuatan stuktur gaji sekolah oleh pimpinan sekolah dan bendahara dapat mempertimbangkan kemampuan finansial sekolah, (4) Tahapan terakhir dalam model penggajian guru yaitu pimpinan sekolah dapat mempertimbangankan pemberian gaji individual kepada guru sesuai dengan jabatan dan tugas yang dibebankan dengan menggunakan manajemen dan verifikasi data yang baik adalah dengan melakukan pengawasan kepada guru setelah kebijakan ditetapkan, dan (5) Hasil akhir dari tahapan-tahapan itu adalah dapat melakukan implementasi, komunikasi dan pengawasan dalam penerapan penggajian guru berbentuk model yang dapat menentukan kebijakan serta acuan.

Adapun rekomendasi yang dapat disampaikan oleh peneliti mengenai penggajian guru berdasarkan perspektif Islam adalah sebagai berikut: a. Keadilan dan kelayakan harus ditetapkan dalam penganggaran dan pemberian gaji kepada guru, keadilan dan kelayakanpun tidak hanya dilihat untuk guru yang menerima gaji namun juga dapat dilihat dan dibandingkan dengan pemberi gaji yaitu pemimpin sekolah. Keadilan dan kelayakan akan sangat berpengaruh dalam pemberian gaji dan pengganggaran gaji untuk guru dan karyawan sekolah. Sehingga tercapai tujuan untuk mensejahterakan pekerja khususnya guru.

Model penggajian guru dapat dilakukan dengan lebih baik dan terarah apabila telah memiliki model khusus yang berkaitan dengan Model penggajian guru berdasarkan perspektif Islam.

\section{DAFTAR PUSTAKA}

Al-Qur'an

As-Sunnah

(2015, 6 20). Undang-undang Ketenagakerjaan.

A.R Tilaar, 2. (2002). Pendidikan dan Kebudayaan Masyarakat Madani Indonesia. Bandung: Remaja Rosdakarya.

Affar, M. A. (1985). Al-Iqtishad al-Islami, Jilid. 3. Jeddah: Dar al-Bayan alArabi.

Decenzo, A. D. (2009). Fundamentals of Human Resource Management. USA: Willey.

Hakim, M. S. (1989). Hubungan MajikanPekerja Menurut Islam, (terjemahan Yusuf Ismail). Kuala Lumpur: A.S. Noorden.

Hamzaid, B. Y. (1998). Ekonomi Mikro, edisi $k e-3$, cet ke-9. Kajang: $\mathrm{B} \& \mathrm{H}$ Enterprise, Sdn. Bhd.

Indonesia, D. A. (2005). al-Qur'an dan Terjemahan. Jakarta: Syamil Cipta Media.

Jafri, S. (2008). Fiqih Muamalah. Pekanbaru: Suska Press.

Khera, H. S. (1978). Mikroekonomi: Prinsipprinsip dan Aplikasi-aplikasi, (terjemahan Moh. Kaus Tajudin). Petaling Jaya: Khera Sdn. Bhd. 
Kosasi, S. d. (1999). Profesi Keguruan. Jakarta: PT Rineka Cipta.

Kosim, M. (2008). Guru dalam Perspektif Islam. Tadris Volume 3. Nomor 1. , 49.

Mankiw N, G. d. (2012). Pengantar Ekonomi Makro. Jakarta: Salemba Empat.

Mannan, M. A. (1993). Ekonomi Islam: Teori dan Praktek, (terjemahan Radiah Abd. Kader) bagian IV, Juz 3. Kuala Lumpur: A.S. Noorden.

Marlina, M. E. (2013). Kurikulum 213 yang Berkarakter. Jurnal Jupiis Volume 5 Nomor 2, Hlm 30. Diakses.

Moleong, L. J. (2013). Metode Penelitian Kualitatif. Edisi Revisi. Bandung: PT. Remaja Rosdakarya.

Mulyono, M. (2004). Penerapan Produktivitas Dalam Organisasi. Jakarta: Bumi Aksara.

Qardhawi, Y. A. (1995). Daur al-Qiyam wa al-Akhlaq fi al-Iqtishad al-Islami. Kairo: Maktabah Wahbah.

Rahman, A. (1995). Economic Doktrines of Islam, Terj. Soeroyo dan Nastangin, "Doktrin Ekonomi Islam", Jilid II. Yogyakarta: PT Dana Bhakti Wakaf.

Ramayulis. (2005). Metodologi Pendidikan Agama Islam. Jakarta: Kalam Mulia.

Ridwan, M. (2013). Standar Upah Pekerja Menurut Sistem Ekonomi Islam. Volume 1, No.2, Desember 2013, 241257.

Roqib, M. N. (2009). Kepribadian Guru Upaya Mengembangkan Kepribadian Guru yang Sehat di Masa Depan. Yogyakarta: Grafindo Litera Media.

S.R., S. (2006). Akuntansi Suatu Pengantar. Jakarta: Salemba Empat.

Salim, M. N. (2013.). Tenaga Kerja dan Upah dalam Perspektif Islam. Makalah Etika Bisnis Islam.

Samsudin, S. (2006). Manajemen Sumber daya Manusia. CV. Pustaka Setia.

Subekti. (1995). Aneka Perjanjian. Bandung: Citra Aditya Bakti.

Sugiyono. (2015). Metode Penelitian Kuantitatif, Kualitatif, dan R\&D. . Bandung: ALFABETA.
Sukirno, S. (1994). Pengantar Teori Ekonomi Makro. Jakarta: Raja Grafindo.

Sulaiman, F. H. (1990). Konsep Pendidikan Al-Ghazali, terj. Ahmad Hakim dan Imam Azis. Jakarta: P3M.

Sumarsono, S. (2003). Ekonomi Manajemen Sumber Daya Manusia dan Ketenagakerjaan. Yogyakarta: Graha Ilmu.

Supriadi, D. (2004). Peningkatan Kualitas Layanan Bimbingan dan Konseling di Sekolah. Jurnal Ilmu Pendidikan Vol. 1 No.1.

Suryabrata, S. (2008). Metodologi Penelitian. Jakarta: PT. Raja Grafindo Persada.

Tafsir, A. (2001). Ilmu Pendidikan Dalam Perspektif Islam. Bandung: PT Remaja Rosdakarya.

Winardi. (1998.). Kamus Ekonomi, cet ke16. Bandung.: Penerbit Mandar Maju.

Yunus, M. I. (2009). Pengantar Ekonomi Islam,. Bogor: al-Azhar Press. 